\title{
Earning Per Share Under International Accounting Regulations and Based on the Example of Companies Listed on the Warsaw Stock Exchange
}

\author{
Piotr Prewysz-Kwinto \\ WSB University in Torun, Department of Finance and Accounting Poland, \\ Grażyna Voss \\ University of Technology and Life Sciences, Faculty of Management, Bydgoszcz, Poland,
}

\begin{abstract}
:
Earnings per share is one of the most important financial ratios facilitating investors make decisions about the choice of a company to invest in. To fulfill this role, it should be calculated according to the same rules by all companies, so that the results can be compared correctly. Therefore, the IASB (International Accounting Standards Board) issued a special standard comprehensively regulating the rules of its calculation and presentation in financial statement. It is International Accounting Standard 33 - Earning per share, which was released in December 2003. It was first applied to financial statements prepared for the reporting period starting after January 1, 2005. The standard was revised once - in 2008. This standard requires calculation and presentation in financial statement basic and diluted earnings per share and accurately specifies how to do it. The aim of this paper is to describe the rules of calculating, presenting and disclosure information about earning per share under IAS 33 as well as to analyze the presentation of such information in financial statements of the largest companies listed on the Warsaw Stock Exchange. The main methods used include the analysis and evaluation of legal acts and subject-related literature as well as the analysis of information disclosed in financial statements of the largest companies listed on the Warsaw Stock Exchange.
\end{abstract}

Keywords: earning per share, International Accounting Standard, accounting regulations, financial statement, financial ratios.

\section{Introduction}

Earnings per share (EPS) is a popular financial ratio which is widely used by investors worldwide. It measures potential profit on investment in company's shares (Sierpinska, Jachna, 2004, p. 214). It is important for both investors who count on a profitable dividend as well as those who expect an increased market value of shares resulting from, for example, the increasing profit (Golebiewski, Tlaczala, 2005, p. 143). The EPS value also affects the market price of shares, and hence translates into an increased total corporate value (Jerzemowska, 1999, p. 135). For investors, it may be a crucial indicator used to build investment strategies and portfolio (Nowak, 2017, p. 226). It is also a basis for calculating other capital market ratios such as P/E or DPR (Dynus, Kolosowska, Prewysz-Kwinto, 2005, p. 99-101).

EPS is reliable provided that it is calculated using the same principles, and thus enabling comparisons between different reporting periods and different entities. Nowadays, however, joint-stock companies can issue various types of shares which differ, for example, in offered preferences. Moreover, as a result of a dynamic development of the financial market, a wide range of instruments has emerged which under specific conditions can be converted into shares (options, convertible bonds), and hence can increase the number of shares and affect the EPS value. Therefore, it was necessary to prescribe specific principles for calculating earnings per share. 
The aim of this paper is to describe the rules of calculating, presenting and disclosure information about earning per share under IAS 33 as well as to analyze the presentation of such information in financial statements of the largest companies listed on the Warsaw Stock Exchange.

The main methods used include the analysis and evaluation of legal acts and subject-related literature as well as the analysis of information disclosed in financial statements of the largest companies listed on the Warsaw Stock Exchange.

\section{EPS under international accounting regulations}

The principles for calculating earnings per share have been prescribed in detail in a separate standard - IAS 33 Earning per share, which was first adopted in February 1997, effective from January 01, 1999. So far the standard has been amended twice and its version as of August 07, 2008, is now in effect. The objective of the standard is to prescribe principles for the determination and presentation of earnings per share in order to enable performance comparisons between different entities in the same reporting period as well as different reporting periods for the same entity. The most important requirement of IAS 33 is the calculation and presentation of two amounts of EPS in the financial statements - basic and diluted.

\subsection{Basic earnings per share}

Basic earnings per share is a ratio of profit (or loss) generated by an entity in the reporting period for which it is calculated and which is attributable to ordinary equity holders of the parent entity and weighted average number of ordinary shares during the same reporting period. The requirement to determine the ratio for ordinary shares makes it necessary to adjust the numerator, i.e. profit or loss if the entity apart from ordinary shares has also issued preference shares. Thus, in accordance with paragraph 14 of IAS 33, the net income for the period should be adjusted by the amounts of dividends on preference shares as well as all equivalent payments. The EPS value should be calculated according to the following formula:

$$
\text { EPS }=\frac{\text { earning after taxes }- \text { dividends on preference shares }}{\text { weighted average number of ordinary shares }}
$$

The requirement to include the weighted average number of ordinary shares in the denominator results from the fact that in the period the number of such shares can change because, for example, new shares have been issued or existing ones have been bought back, which affects the equity. The denominator is thus determined as the number of ordinary shares at the beginning of the period adjusted by the number of shares bought back or issued during the period multiplied by a timeweighting factor. The time-weighting factor is a quotient of the number of days that the shares are outstanding and the total number of days in the period. In practice, while determining the value of this factor, there might be some problems resulting from the correct determination of the date from which the shares should be included. Potential situations have been elaborated in paragraph 21 of IAS 33.

While calculating the weighted average number of shares, not only changes in the shares number which affect the equity are considered but also those which do not affect the equity, for example, bonus issue (stock dividend), share split or consolidation of shares.

\subsection{Diluted earnings per share}

The diluted EPS calculation is required due to the existence of financial instruments which under specific conditions can be converted into ordinary shares and thus increase the number of shares and reduce basic EPS. A dilutive instruments is called a potential ordinary share and is defined as a financial instrument or contract which entitles its holder to ordinary shares. They include: financial liabilities or equity instruments that are convertible to shares (e.g. convertible bonds), options and warrants as well as shares that would be issued upon the satisfaction of certain conditions (Holda, 2013, p. 251). The 
basis for calculating diluted EPS is the basic EPS, the nominator and denominator of which are adjusted by dilutive effects of potential ordinary shares (Helin, 2006, p. 195). The nominator is adjusted if the conversion of potential shares could affect the profit or loss generated by the entity. An example of such a situation is the exercise or conversion of convertible bonds into shares, as as result of which the entity ceases to pay interest (bonds cease to exist), which increases its profit or loss and reduces financial expenses. Potential adjustments of the nominator resulting from the exercise of potential ordinary shares are presented in detail in paragraph 33 of IAS 33.

The denominator is adjusted meaning that the weighted average number of ordinary shares is increased by the weighted average number of additional shares that would have been outstanding as assuming the conversion of all potential shares. As in the case of the basic EPS calculation, potential ordinary shares are weighted for the period they are outstanding. Detailed methods of including potential ordinary shares in the calculation of EPS depend on a share type and as there are many of them, they will not be presented in this paper.

\subsection{Presentation and disclosures of earnings per share}

Principles for the presentation of earnings per share in the financial statements are prescribed in paragraphs 66-69 of IAS 33. An entity is required to disclose basic and diluted earnings per share for profit or loss (including continuing operations) attributable to ordinary equity holders of the parent entity. The presentation of EPS (basic and diluted) depends on the adopted method of information presentation in the statement of comprehensive income [IAS 33.67A]. In accordance with IAS 1, an entity presents profit or loss in a single statement - statement of profit or loss and other comprehensive income. EPS is presented separately if an entity prepares two separate statements, i.e. statement of profit or loss and statement of comprehensive income - EPS is presented in the former. Moreover, an entity that reports a discontinued operation is required to disclose basic and diluted earnings per share for the discontinued operation in the statement of profit or loss or in the notes.

If EPS is presented, the following disclosures are required [IAS 33.70]:

- the amounts used as the numerators in calculating basic and diluted EPS, and a reconciliation of those amounts to profit or loss attributable to the parent entity for the period

- the weighted average number of ordinary shares used as the denominator in calculating basic and diluted EPS, and a reconciliation of these denominators to each other

- instruments (including contingently issuable shares) that could potentially dilute basic EPS in the future, but were not included in the calculation of diluted EPS because they are antidilutive for the period(s) presented

- a description of those ordinary share transactions or potential ordinary share transactions that occur after the balance sheet date and that would have changed significantly the number of ordinary shares or potential ordinary shares outstanding at the end of the period if those transactions had occurred before the end of the reporting period.

Complicated economic reality creates a number of situations that will affect the earnings per share ratio - basic and diluted. Therefore, an attempt was made to verify whether and how the largest capital groups listed on the Warsaw Stock Exchange comply with the requirement of presentation and disclosure of earnings per share imposed by IAS 33. It should also be noted that such a study concerning Polish stock exchanges has not yet been conducted.

\section{Study methodology and study group}

The study included the largest capital groups listed on the Warsaw Stock Exchange, i.e. those groups which on February 10, 2017, were included in two major indices: WIG201 and mWIG402. For the purpose of a detailed analysis, the study entities were divided according to the type of business activity, and the results are presented in Table 1.

1 WIG20 is an index which comprises 20 largest companies listed on the WSE, selected in respect of capitalization and turnover value. $2 \mathrm{mWIG} 40$ is an index which comprises 40 largest companies listed on the WSE, following the 20 companies of WIG20. 
Table 1. Analysed entities according to the type of conducted business activity

\begin{tabular}{|l|l|l|}
\hline Industry & Number of companies & Share \\
\hline Automotive & 3 & $5,0 \%$ \\
\hline Chemical and fuel & 6 & $10,0 \%$ \\
\hline Construction & 6 & $10,0 \%$ \\
\hline Electromechanical & 2 & $3,3 \%$ \\
\hline Energy & 4 & $6,7 \%$ \\
\hline Financial services & 12 & $20,0 \%$ \\
\hline Food & 2 & $3,3 \%$ \\
\hline IT & 4 & $6,7 \%$ \\
\hline Metal & 4 & $6,7 \%$ \\
\hline Mining & 3 & $5,0 \%$ \\
\hline Other & 5 & $8,3 \%$ \\
\hline Retail and wholesale & 5 & $8,3 \%$ \\
\hline Telecommunications & 2 & $3,3 \%$ \\
\hline Wood and paper & 2 & $3,3 \%$ \\
\hline Total & 60 & $100,0 \%$ \\
\hline
\end{tabular}

Source: author's compilation.

In the study group companies from the financial sector (banks and insurance companies) had the biggest share - chemical and fuel sectors constituted $20 \%$ and construction and property development sectors $10.9 \%$ each. Other included capital groups from such sectors as: catering, hotel, media, transport and other services. Among the WIG20 entities, entities from financial, fuel and energy sectors were dominant while in mWIG40 financial as well as construction and property development sectors. In accordance with the Polish Accounting Act, all entities, being capital groups listed on the WSE, prepared financial statements under international standards IAS/ IFRS while the analysis included consolidated financial statements prepared for fiscal year 2015 or fiscal year which ended in 2015. It is connected with the fact that complete financial statements for year 2016 were not yet available while preparing this paper.

\section{Study results}

At the beginning of the study it was checked whether the study entities calculated and presented earnings per share in the statement of profit or loss as required by IAS 33. The analysis showed that EPS was presented by $98.3 \%$ of the companies, including all groups from mWIG40 and 95\% from WIG20. One group which did not present EPS directly in the statement of profit or loss presented it in the introduction to the financial statements in selected and consolidated financial data. The results allow to conclude that all the study entities comply with the requirement set out in IAS 33 .

Next, it was determined in which line of the statement of profit or loss the entities presented information on earnings per share. The analysis showed that the line strictly depended on the method adopted by the entity to present disclosures on profit or loss and comprehensive income. According to the currently effective IAS 1 Presentation of Financial Statements, an entity may choose how to present such disclosures, i.e. in a single statement (statement of comprehensive income) or two separate statements, i.e. statement of profit or loss and statement of comprehensive income which begins with a net income. The groups which adopted the first method, i.e. presentation of profit or loss in a single statement, presented EPS 
at the end of the statement while those which prepared two separate statements presented EPS directly after the profit or loss and before the statement of comprehensive income. The results are presented in Chart 1.

Chart 1. EPS presentation line in the statement of profit or loss

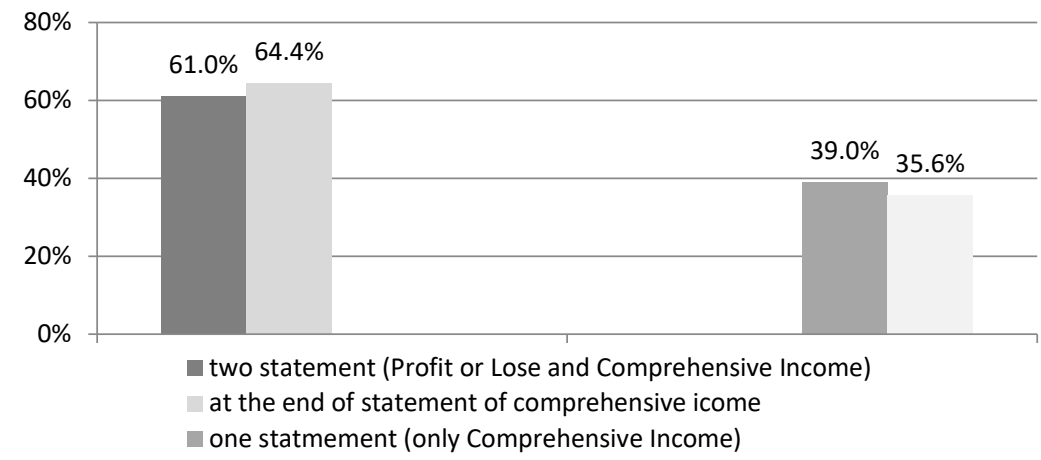

Source: author's compilation.

As Chart 1 shows, the study entities more often decided to present disclosures on profit or loss in two separate statements, and thus more often (64.4\%) presented EPS directly after the net income and before the statement of comprehensive income. On the other hand, $35.6 \%$ of the study entities decided to present EPS at the end of the statement of comprehensive income. The analysis in respect of the size of a group (based on belonging to WIG20 and mWIG40) did not show significant differences. The first presentation method - that is presentation of EPS after the statement of profit or loss and before the statement of comprehensive income - was selected by $68.4 \%$ of the WIG 20 groups and $62.5 \%$ of mWIG 40 . The second method - after the statement of comprehensive income - was selected by $31.6 \%$ of the WIG20 groups and $37.5 \%$ of mWIG40. Moreover, a detailed analysis in respect of the type of business activity allowed to conclude that for some sectors EPS was more frequently presented in a specific line. It was noted that EPS was presented directly after the net income and before disclosures on comprehensive income by all financial business companies, $83.3 \%$ of construction and property development companies and $66.6 \%$ of chemical business companies. In the case of companies which presented EPS at the end of the statement of comprehensive income, energy, IT and metal business groups were dominant $-75 \%$ each.

In accordance with IAS 33, entities are required to calculate and present two earnings per share: basic and diluted. Thus, in the next part of the study an attempt was made to determine in how many capital groups under the study dilutive factors appeared and whether those factors significantly affected EPS.

Factors diluting the number of shares appeared in $25 \%$ of all the capital groups under the study and that share was equal for WIG20 and mWIG40 groups. A detailed analysis in respect of the type of business activity showed, on the other hand, that among all sectors represented by the study entities dilutive factors were more frequent for retail and wholesale trade companies - it was the case for $80 \%$ of the groups conducting such business.

The analysis of the influence of dilutive factors on EPS immediately showed that for over one fourth of the study entities in which the factors had appeared (i.e. 26,7\%), they were insignificant and did not affect the basic EPS amount. For the remaining entities, i.e. those in which dilution appeared and affected EPS (73.3\%), an attempt was made to determine whether the change was significant. For this purpose a percentage difference between basic and diluted EPS amounts was calculated. For $81.8 \%$ of the entities the difference was insignificant and was less than $5 \%$ (for over half of the entities it did not exceed 1\%). Only in the case of two entities (which constituted $18.2 \%$ ) was the difference significantly higher and reached over $15 \%$, i.e. $16.4 \%$ and $27.0 \%$ respectively. Nevertheless, considering the whole study group it may be 
concluded that factors influencing the dilution appear rarely and cause insignificant differences between basic and diluted EPS amounts. Significant differences appear rarely and in this study they were the case for barely $3.3 \%$ of the study entities.

The groups in which dilutive factors have appeared appear present basic and diluted EPS amounts separately in accordance with IAS 33. What is more, they present both amounts in the consecutive reporting periods, even if dilutive factors no longer appear and basic and diluted EPS amounts are equal. In such a case, under IAS 33 dual presentation can be accomplished in one line. Therefore, in the next part of the study, the groups in which dilutive factors did not appear (they constituted $75 \%$ of all the groups) were analysed in respect of the method of presenting EPS in the financial statements. The results are presented in Chart 2.

Chart 2. Presentation of equal basic and diluted EPS amounts

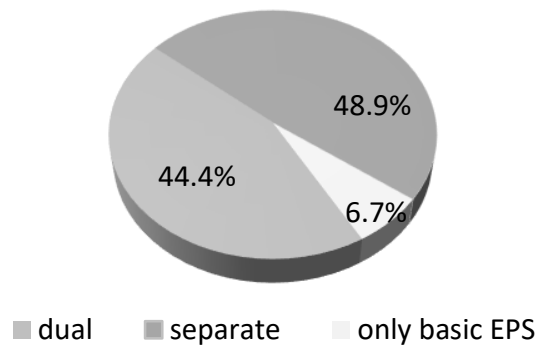

Source: author's compilation.

From all entities in which dilution of shares did not appear, $44.4 \%$ chose dual presentation of EPS in one line usually named profit (loss) per share: basic and diluted while $48.9 \%$ chose separate presentation. In the case of the remaining $6.7 \%$, only basic EPS was presented since dilutive factors had not appeared in any of the previous reporting periods. A detailed analysis of the information presentation in respect of the size of the group based on belonging to WIG20 or mWG40 showed significant differences. The WIG20 capital groups more often presented EPS in one line (80\%) rather than in two separate lines $(20 \%)$. In the case of the mWIG40 capital groups, a separate presentation was more dominant $(63.3 \%)$ than dual presentation $(26.7 \%)$.

In accordance with IAS 33, an entity that reports a discontinued operation in accordance with IFRS 5 shall also calculate EPS amount for the discontinued operation and disclose the amount either in the statement of profit or loss or in the notes. However, the satisfaction of that requirement was impossible to verify as only one capital group had disclosed such an operation in the statement of profit or loss. The group, however, presented only earnings per share amount for the whole operation (continuing and discontinued) and did not prepare any notes to EPS.

In the next part of the study, the notes to financial statements were analysed as under IAS 33 entities are required to disclose principles for the EPS calculation. First, it was examined how many study entities prepared the notes to that item of the financial statements. The results showed that $83.3 \%$ of the study entities included it in the financial statements - $80 \%$ of the WIG20 groups and $85 \%$ of the mWIG40 groups. Thus, no differences were observed in respect of the size of the group. What is more, entities which did not prepare a separate note to EPS reported additional information on basic and diluted numbers of shares directly in the statement of profit or loss.

Next, the nature and scope of disclosures in the notes were examined. It was checked whether the entities disclosed information on the number of shares that was the basis for the earnings per share calculation, a change in this number in the examined period, and if any change, what the reason for that change was. It was also checked whether profit or loss that was the basis for the earnings per share calculation was reported and whether details on dilutive factors were presented. The analysis showed that all study entities disclosed information on the number of shares that was the basis for 
the earnings per share calculation and the net income, i.e. information required by IAS 33. The situation was different for disclosures on the reasons for the number of shares changes, if such changes appeared, and on dilutive factors. From the entities in which a change in the shares number in the studied period appeared (they constituted $30 \%$ of all the entities), only $27.8 \%$ provided the reasons. However, such disclosures were frequently reported in the notes to equity. In the case of entities in which dilutive factors appeared in the studied period and which also presented the notes $(21.7 \%$ of all the entities), $92.3 \%$ provided detailed reasons for dilution. It usually resulted from options per share issued within incentive plans for managers or from the issue of convertible bonds.

Finally, the analysis of disclosures in the notes verified the method of information presentation adopted by the study entities, i.e. whether it was a description or numerical table, or both. The results are presented in Chart 3.

Chart 3. Presentation of information in the notes

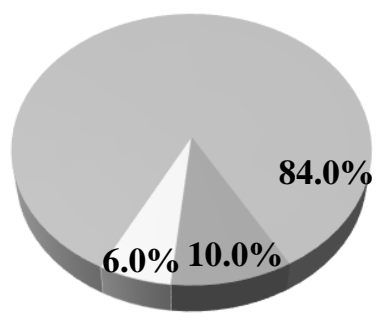

$\square$ only numerical table $\square$ only description $\square$ both

Source: author's compilation.

Usually the notes regarding earnings per share were presented both in a numerical table and in descriptions of reasons for changes in the number of shares or dilutive factors. Such a method was adopted by $84 \%$ of the entities which prepared the notes. The method was more frequently adopted by larger WIG20 groups $(93.8 \%)$ rather that smaller mWIG40 groups $(79.4 \%)$. Smaller groups more often presented information only in a table or only in a description without disclosing specific figures. Descriptions varied greatly - some groups presented synthetic information in a few short sentences, other presented detailed information significant for the earnings per share calculation.

Finally, the study verified if and how principles for the presentation and disclosures regarding earnings per share had been described in the accounting policy which is a constituent of financial statements. What should be first indicated is that $5 \%$ of the study groups did not include any description of principles for the assets and liabilities presentation in the published financial statements. Only $26.7 \%$ of the remaining entities which included their accounting policies described principles for the presentation and disclosures on earnings per share. It might be related to the fact that IAS 33 exactly prescribes the principles for the EPS presentation and calculation, and the study entities did not want to copy those principles in their financial statements. Almost $90 \%$ of the entities which described principles for the earnings per share presentation in their accounting policy copied the principles set out in IAS 33 and limited the description to presenting principles for the EPS calculation.

\section{Conclusions}

Based on the analysis of financial statements of selected capital groups listed on the WSE which concerned the principles for the presentation and disclosures of earnings per share, the following conclusions can be drawn:

- capital groups under the study meet the requirement under IAS 33 and present information on earnings per share in the statement of profit or loss. 
- the information presentation line in the statement profit or loss depends on the method of its preparation. If an entity prepares a statement of profit or loss and statement of comprehensive income separately, EPS is presented directly after the statement of profit or loss. If an entity prepares only a statement of comprehensive income, EPS is presented at the end of the statement.

- in 2015 dilutive factors were not frequent and appeared in only $25 \%$ of the study entities.

- the influence of dilutive factors on EPS remains insignificant and for $86 \%$ of the study entities the difference between basic and diluted EPS amounts did not exceed $5 \%$.

- not all entities disclosed information on earnings per share in a separate note; disclosures on the number of shares and net income constituting the basis for the EPS calculation which are required under IAS 33 were presented directly in the statement of profit or loss.

- detailed information included in the notes was presented both in numerical tables or in descriptions; almost all entities in which dilutive factors appeared described why they had appeared in detail.

\section{References:}

[1] Dynus M., Kolosowska B., Prewysz-Kwinto P., Analiza finansowa przedsiębiorstwa, TNOiK, Torun 2005.

[2] Gołębiowski G., Tłaczała A., Analiza ekonomiczno-finansowa w ujęciu praktycznym, Diffin, warszawa 2005.

[3] Helin A, Sprawozdanie finansowe według MSSF. Zasady sporządzania i prezentacji, C. H. Beck, Warszawa 2006.

[4] Holda A., MSR/MSSF w polskiej praktyce gospodarczej, C.H. Beck, Warszawa 2013.

[5] Jerzemowska M., Kształtowanie struktury kapitału w spółkach akcyjnych, PWN, Warszawa 1999.

[6] MSR 1 - Presentation of Financial Statement, Commission Regulation (EC) No 1255/2012 of 11 December 2012, OJ L 360, 29.12.2012.

[7] MSR 33 - Earning per share, Commission Regulation (EC) No 1126/2008 of 3 November 2008, OJ L 320, 29.11.2008.

[8] Nowak E., Analiza sprawozdań finansowych, PWE, Warszawa 2017.

[9] Sierpinska M., Jachna T., Ocena przedsiębiorstwa według standardów światowych, PWN, Warszawa 2004.

[10] The financial statements of entities included in the WIG-30 index: WIG20 i mWIG40. 